\title{
Optimizing zinc seed coating treatments for improving growth, productivity and grain biofortification of mungbean
}

\author{
Muhammad Umar Haider ${ }^{1}$, Mubshar Hussain ${ }^{1,2^{*}}$ and Muhammad Farooq ${ }^{3,4}$ \\ ${ }^{1}$ Department of Agronomy, Bahauddin Zakariya University, Multan, Pakistan \\ ${ }^{2}$ Agriculture Discipline, College of Science, Health, Engineering and Education Murdoch University, \\ 90 South Street, Murdoch, WA 6150, Australia \\ ${ }^{3}$ Department of Agronomy, University of Agriculture, Faisalabad, Pakistan \\ ${ }^{4}$ Department of Crop Sciences, College of Agricultural and Marine Sciences, Sultan Qaboos University, \\ Al-Khoud-123, Oman
}

\section{Abstract}

Zinc $(\mathrm{Zn})$ is a crucial micronutrient required by plants and human beings. In this study, it was hypothesized that $\mathrm{Zn}$ seed coating may improve the stand establishment, growth, grain Zn biofortification and seed yield of mungbean (Vigna radiata (L.) Wilczek). The experiment consisted of four seed coating treatments viz. 0.50, 1.0, 1.5 and $2 \mathrm{~g}$ of $\mathrm{Zn} \mathrm{kg}^{-1}$ seed; non-coated seeds being taken as control. The findings of this study disclosed that Zn seed coating was beneficial for enhancing the seedling growth, morphological and yield parameters, grain yield and

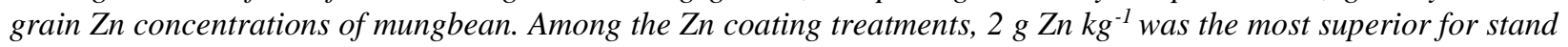
establishment, seedling growth, morphological/yield parameters, grain yield and grain Zn biofortification. Zn seed coating increased the seed yield of mungbean by 6.8-40.6\% and grain Zn concentration by 12.0-34.4\%, respectively, than the non-coated seeds. Thus, the mungbean seeds should be coated with $2 \mathrm{~g} \mathrm{Zn} \mathrm{kg-1}^{-1}$ to achieve better stand establishment, seedling growth, morphological and yield parameters, seed yield and grain Zn biofortification.

Keywords: Zinc, seed coating, mungbean, malnutrition, biofortification

\section{Introduction}

Pulses are consumed by billions of people across the globe. Indeed, the protein available through pulses is easily accessible by the poor people (Usman et al., 2007). Among all pulses, mungbean (Vigna radiata L.) Wilczek) is an ancient and valuable pulse crop due to its nutritional worth (Shanmugasundaram, 2004). It is a short period crop which can be grown in spring as well as summer season in Pakistan. It is a marvelous crop having excellent quality protein which is easily digestible. Mungbean crop may have protein contents of 18 to $25 \%$. Besides its nutritional value, mungbean is also beneficial for improvement of soil fertility due to its natural ability to fix the atmospheric nitrogen (Ashraf et al., 2003).

However, the average yield of mungbean in Pakistan is lower than most of the countries of the world. The reasons for this low yield include the poor stand establishment, biotic and abiotic stresses and little use of micronutrients at farmer field. Among these micronutrients, the Zn deficiency is regarded as an important factor for decreasing the mungbean yield. Indeed, $\mathrm{Zn}$ is necessary for protein synthesis (Cakmak, 2008), DNA synthesis, cell division
(Nadergoli et al., 2011), proper functioning of pollen, fertilization, germination and chlorophyll production (Cakmak, 2008). Thus, the Zn deficiency may hamper the growth of legumes including mungbean.

In plants, Zn can be applied through various methods (Zafar et al., 216; Haider et al., 2018a, b; Ullah et al., 2019). For instance, $\mathrm{Zn}$ foliage application enhanced the growth, seed yield and grain $\mathrm{Zn}$ concentration in mungbean (Haider et al., 2018a). The soil applied micronutrients are pragmatic solution for reducing the micronutrient deficiencies in crop plants like mungbean (Haider et al., 2018b). However, both soil and foliar application have some limitation. For example, soil application required high quantities of micronutrients and the uptake of the micronutrients may be affected due to soil properties (Koca, 2016). The environmental conditions may affect the efficacy of foliage applied micronutrients (Fageria et al., 2009) thus decreasing the wide scale adoption of foliar application at farmers' field.

In this scenario, seed treatments viz. seed coating, seed pelleting, might be a useful option for micronutrient delivery to seed in order to improve the performance of

*Email: mubashiragr@gmail.com 
crops (Farooq et al., 2012). Among the seed treatments, seed coating is most beneficial than other seed treatments owing to very low use of micronutrient and direct delivery of the required micronutrient on seed surface. Many studies have reported that seed coating of micronutrients improved the yield of field crops (Wiatrak, 2013; Korishettar et al., 2016; Ullah et al., 2019).

Besides plants, in developing world, the micronutrient deficiencies are exacerbating in humans where most of the people are suffering from poverty (Bhandari and Banjara, 2015). They are unable to purchase the micronutrient fortified food. According to World Health Organization, 2 billion peoples in the world (especially developing countries) are suffering from minerals and vitamin deficiencies. As mungbean is staple of many people in world, improving $\mathrm{Zn}$ concentration in seeds might be a pragmatic option to improve the micronutrient delivery to humans through grains, which will ultimately reduce the malnutrition. Thus, it was hypothesized that $\mathrm{Zn}$ seed coating may improve the stand establishment, seedling growth, morphological and yield parameters, grain yield and grain $\mathrm{Zn}$ concentration in mungbean.

\section{Materials and Methods}

\section{Site and soil}

This study was conducted at Bahauddin Zakariya University, Multan, Pakistan during the summer season of 2016. The climatic conditions of the study site are semi-arid, subtropical. The experimental soil was sandy, having $\mathrm{pH}$ of 8.1 , electrical conductivity of $2.39 \mathrm{dS} \mathrm{m} \mathrm{m}^{-1}$, organic matter of $0.47 \%$, phosphorus of $5.4 \mathrm{mg} \mathrm{kg}-1$, potassium of $160 \mathrm{mg} \mathrm{kg}^{-1}$ and $\mathrm{Zn}$ of $0.61 \mathrm{mg} \mathrm{kg}^{-1}$.

\section{Experimental details}

Seeds of mungbean cultivar NM-2006 were obtained from NIAB, Faisalabad, Pakistan. The experimental treatments comprised of four levels of $\mathrm{Zn}$ seed coating viz. $0.50,1,1.5$ and $2 \mathrm{~g} \mathrm{Zn} \mathrm{kg}^{-1}$ seed using $\mathrm{ZnSO}_{4} .7 \mathrm{H}_{2} \mathrm{O}$ as source of $\mathrm{Zn}$ while non-coated seeds being taken as control. For seed coating, arabic gum was used as sticky material to adhere the $\mathrm{Zn}$ on seeds. After coating, the seeds were dried under shade near to its original weight. The coated seeds were kept in refrigerator $\left(5^{\circ} \mathrm{C}\right)$ in polythene bags, till sowing. The experiment was laid out following completely randomized design and each treatment was replicated four times.

\section{Crop husbandry}

Each pot $(24 \mathrm{~cm} \times 30 \mathrm{~cm})$ was filled with $10 \mathrm{~kg}$ soil. Before mungbean sowing, the pots were irrigated to achieve the favorable moisture conditions for sowing of seeds.
When the moisture level of soil reached at workable level, the soil of pots was manually prepared with hand using a wooden stick. The coated and non-coated seeds were planted in pots on June 19, 2016. Firstly, ten seeds were manually sown in each pot, which were later on thinned to six plants per pot after uniform emergence. Pots were irrigated weekly to avoid any moisture stress. Pots were fertilized at the rate of 60 and $30 \mathrm{~kg} \mathrm{ha}^{-1}$ of phosphorus and nitrogen, respectively, using triple super phosphate and urea as source. The weeds in pots were pulled out manually. The crop was harvested on September 27, 2016.

\section{Data recording}

The pots were visited daily to record the emergence of seedlings each day. Mean emergence time and emergence index were calculated as detailed by Ellis and Roberts (1981) and Association of Official Seed Analysts (1983), respectively. The final emergence count was estimated as the total number of seedlings emerged to the total number of seeds sown in a pot and was expressed in percentage. Energy of emergence was taken as the percentage of emerged seeds from sowing to $4^{\text {th }}$ day of emergence.

Plant sampling was done at 40, 55 and 70 days after sowing (DAS) of crop to record the root length, leaf area per plant, number of lateral roots, and root/stem/leaf dry weights. The final plant height was recorded at harvest with the help of measuring scale for all the plants in a pot and was averaged. The chlorophyll contents were estimated using the SPAD-502 chlorophyll meter at 40 DAS. Total numbers of vegetative and reproductive branches were calculated from every plant and then averaged. The pod length of 10 pods was measured with a measuring scale and was averaged. The numbers of pods per plant in a pot were counted to work out the number of pods per plant. At maturity, the plants from each pot were removed and sun dried for four days. After drying, each plant was weighed with the help of digital balance to measure the biological yield. The pods were threshed manually to compute the grain yield per plant. Ten pods were threshed manually, and the number of seeds was calculated to estimate the seed number per pod. Five sub-sample of 100 seeds were taken from seed lot of each pot and were weighed to record the 100-grain weight. The harvest index was calculated as the ratio of grain yield to the biological yield and was expressed in percentage.

\section{Grain Zn concentrations}

For determining grain $\mathrm{Zn}$ concentrations, the ground seed samples $(0.5 \mathrm{~g})$ were digested in a mixture of $70 \%$ $\mathrm{HClO}_{4}(2: 1 \mathrm{v} / \mathrm{v})$ and $\mathrm{HNO}_{3}(5 \mathrm{~mL})$ in Pyrex digestion flasks for overnight. This was followed by heating this mixture at temperature of $150{ }^{\circ} \mathrm{C}$ on hot plate to the point 
Table 1: Influence of zinc seed coating on early stand establishment of mungbean

\begin{tabular}{lllll}
\hline $\begin{array}{l}\text { Zinc seed coating level }(\mathbf{g} \\
\mathbf{k g}^{-1} \text { of seed) }\end{array}$ & $\begin{array}{l}\text { Energy of } \\
\text { emergence }(\%)\end{array}$ & $\begin{array}{l}\text { Mean emergence } \\
\text { time (days) }\end{array}$ & $\begin{array}{l}\text { Emergence } \\
\text { index }\end{array}$ & $\begin{array}{l}\text { Final emergence } \\
\text { percentage (\%) }\end{array}$ \\
\hline 0.0 & $60 \mathrm{~b}$ & 4.2 & $3.9 \mathrm{~b}$ & $67 \mathrm{c}$ \\
0.5 & $63 \mathrm{~b}$ & 4.8 & $5.4 \mathrm{ab}$ & $77 \mathrm{bc}$ \\
1.0 & $63 \mathrm{~b}$ & 5.0 & $5.9 \mathrm{ab}$ & $83 \mathrm{ab}$ \\
1.5 & $57 \mathrm{~b}$ & 4.2 & $3.9 \mathrm{~b}$ & $70 \mathrm{c}$ \\
2.0 & $80 \mathrm{a}$ & 4.4 & $6.1 \mathrm{a}$ & $93 \mathrm{a}$ \\
$\mathrm{LSD}(p \leq 0.01)$ & 10 & $\mathrm{NS}$ & 2.1 & 10 \\
\hline
\end{tabular}

Table 2: Influence of zinc seed coating on plant height, chlorophyll contents, number of vegetative and reproductive branches, pod length and number of pods per plant of mungbean

\begin{tabular}{lllllll}
\hline $\begin{array}{l}\text { Zinc seed coating } \\
\text { level }\left(\mathbf{g ~ k g}^{-1} \text { of seed) }\right.\end{array}$ & $\begin{array}{l}\text { Plant height } \\
(\mathbf{c m})\end{array}$ & $\begin{array}{l}\text { Chlorophyll } \\
\text { contents } \\
\text { (spade value) }\end{array}$ & $\begin{array}{l}\text { Vegetative } \\
\text { branches per } \\
\text { plant }\end{array}$ & $\begin{array}{l}\text { Reproductive } \\
\text { branches per plant }\end{array}$ & $\begin{array}{l}\text { Pod } \\
\text { length } \\
\text { (cm) }\end{array}$ & $\begin{array}{l}\text { Pods } \\
\text { per } \\
\text { plant }\end{array}$ \\
\hline 0.0 & $37.7 \mathrm{e}$ & $38.4 \mathrm{e}$ & $4.0 \mathrm{~d}$ & $3.0 \mathrm{c}$ & $7.1 \mathrm{~d}$ & $5.0 \mathrm{~d}$ \\
0.5 & $41.0 \mathrm{~d}$ & $39.5 \mathrm{~d}$ & $4.7 \mathrm{~cd}$ & $3.7 \mathrm{bc}$ & $7.4 \mathrm{c}$ & $6.0 \mathrm{~d}$ \\
1.0 & $43.7 \mathrm{c}$ & $41.6 \mathrm{c}$ & $5.3 \mathrm{bc}$ & $4.0 \mathrm{bc}$ & $7.9 \mathrm{~b}$ & $8.0 \mathrm{c}$ \\
1.5 & $48.3 \mathrm{~b}$ & $44.6 \mathrm{~b}$ & $6.0 \mathrm{~b}$ & $4.7 \mathrm{ab}$ & $8.1 \mathrm{~b}$ & $10.0 \mathrm{~b}$ \\
2.0 & $51.3 \mathrm{a}$ & $46.3 \mathrm{a}$ & $7.0 \mathrm{a}$ & $5.3 \mathrm{a}$ & $8.4 \mathrm{a}$ & $11.7 \mathrm{a}$ \\
LSD $(p \leq 0.01)$ & 1.5 & 0.3 & 0.9 & 1.0 & 0.2 & 1.4 \\
\hline
\end{tabular}

when the red fumes production was ceased. Then the temperature of hot plate was moved to $250{ }^{\circ} \mathrm{C}$ until the samples of mixture became the transparent substance. These digested samples were diluted to $25 \mathrm{~mL}$ with distilled water followed by filtration. Grain $\mathrm{Zn}$ contents $\left(\mathrm{mg} \mathrm{kg} \mathrm{kg}^{-1}\right.$ ) were determined using atomic absorption spectrophotometer (Perkin Elmer, CA, USA) following the procedure of Prasad et al. (2006).

\section{Statistical analysis}

Data were analyzed statistically with the assistance of Fisher's ANOVA method and treatments mean along with diversity were assessed by utilizing least significant test (LSD) at 1\% probability level (Steel et al., 1997). For graphical representation of data Microsoft Excel software along with \pm S.E. was used.

\section{Results}

Seed coating significantly affected the final emergence count, emergence index and energy of emergence; results being non-significant for mean emergence time (Table 1). The highest final emergence count, energy of emergence and emergence index were noted when the seeds were coated with $2 \mathrm{~g} \mathrm{Zn} \mathrm{kg}^{-1}$ seed and that was followed by seed coating with 0.5 or $1 \mathrm{~g} \mathrm{Zn} \mathrm{kg}^{-1}$ seed for emergence index and with $1 \mathrm{~g} \mathrm{Zn} \mathrm{kg}^{-1}$ seed for final emergence count (Table 1). The mungbean grown through non-coated seeds had poor seedling growth and seed yield.
Periodic data (Figure 1a-f) indicated that root length, number of lateral roots, root/stem/leaf dry weight and leaf area per plant was gradually enhanced starting from 40 to 70 days after sowing. Among all the seed coating treatments, seed coating at $2 \mathrm{~g} \mathrm{Zn} \mathrm{kg}^{-1}$ seed was most beneficial for improvement in root length, number of lateral roots, leaf area per plant, and root/stem/leaf dry weight at all sampling dates; while the plants grown in control pots performed poor in this regard (Figure 1a-f).

The chlorophyll contents, morphological traits (vegetative/reproductive branches, plant height, pod length), yield parameters (100-seed weight, pods per plant, seeds per pod), biological yield, grain yield and grain $\mathrm{Zn}$ concentrations were significantly affected by various $\mathrm{Zn}$ seed coating treatments (Tables 2 and 3). The highest number of vegetative and reproductive branches, plant height, pod length, chlorophyll contents, pods per plants, 100 -grain weight, biological and grain yield were noted with $\mathrm{Zn}$ seed coating at $2 \mathrm{~g} \mathrm{Zn} \mathrm{kg}^{-1}$ seed and that was statistically similar with $1.5 \mathrm{~g} \mathrm{Zn} \mathrm{kg}^{-1}$ seed for the number of reproductive branches per plant (Tables 2 and 3). Different $\mathrm{Zn}$ seed coating treatments increased the yield of mungbean by $6.8-40.6 \%$; $\mathrm{Zn}$ seed coating at $2 \mathrm{~g} \mathrm{Zn} \mathrm{kg}^{-1}$ seed was the best treatment with $40.6 \%$ improvement in grain yield. Nonetheless, different $\mathrm{Zn}$ seed coating treatments enhanced the grain $\mathrm{Zn}$ concentration by $12.0-34.4 \%$, respectively, than the non-coated seeds. However, the maximum improvement in grain $\mathrm{Zn}$ concentration (34.4\%) was resulted by $\mathrm{Zn}$ seed coating at $2 \mathrm{~g} \mathrm{Zn} \mathrm{kg}^{-1}$ seed (Table 3). 


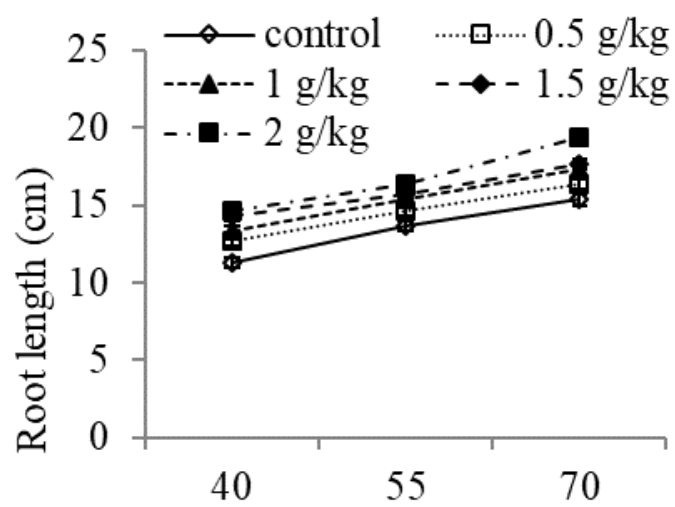

(a)

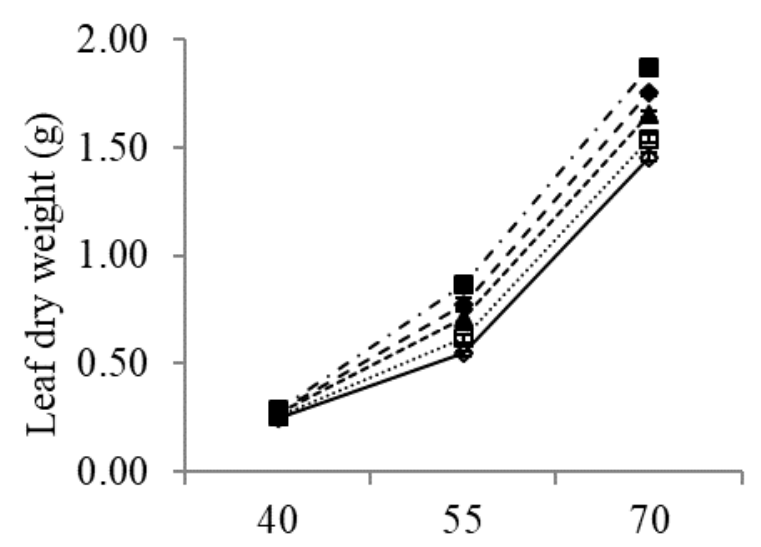

(c)

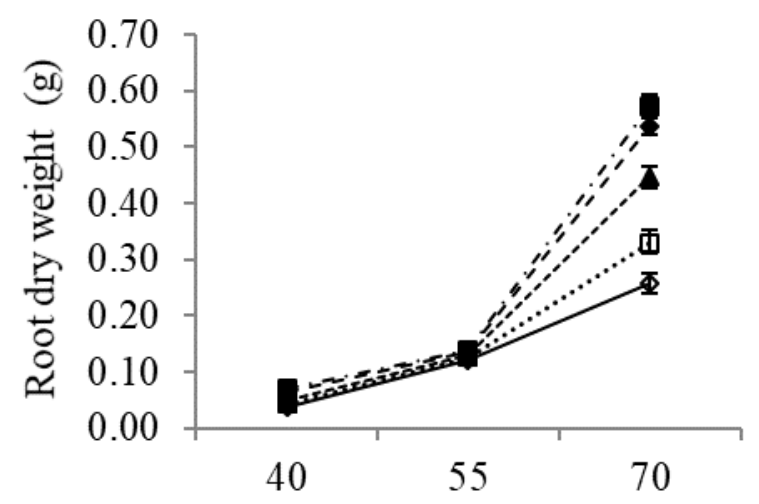

(e)

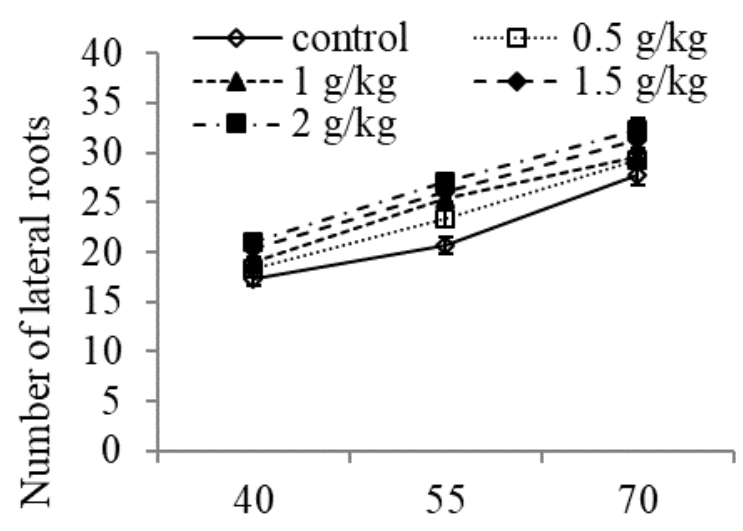

(b)

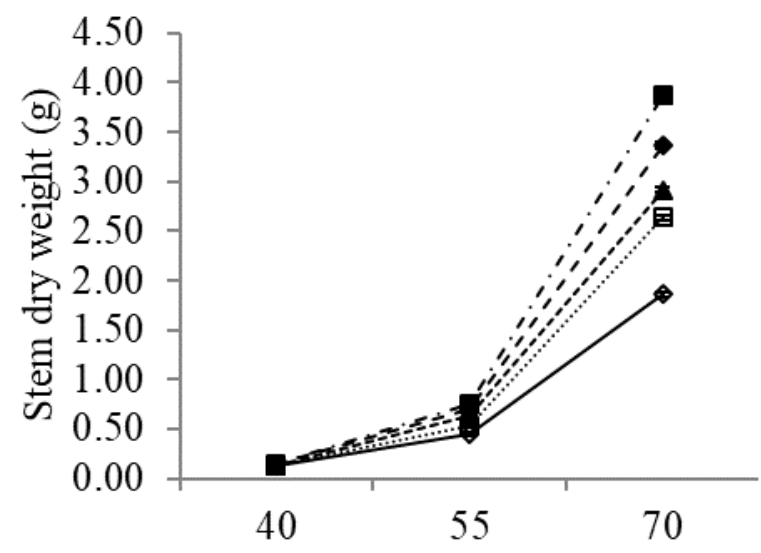

(d)

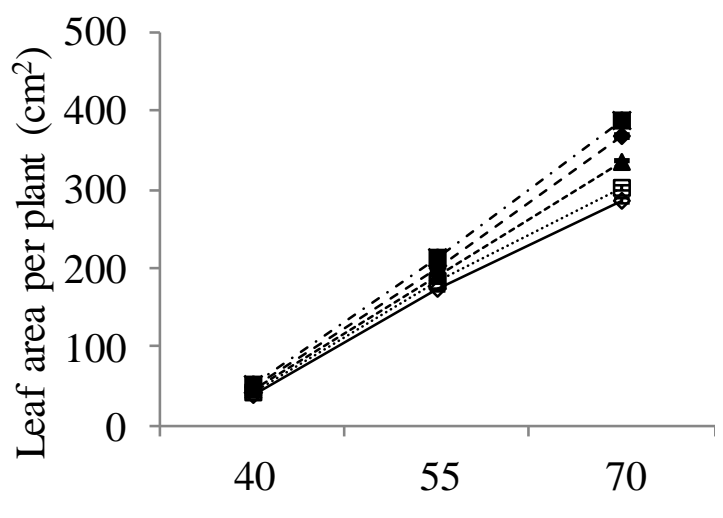

(f)

\section{Days after sowing}

Figure 1: Influence of zinc seed coating on root length (a), number of lateral roots (b), leaf dry weight (c), stem dry weight (d), root dry weight (e) and leaf area per plant (f) $( \pm \mathrm{SE})$ of mungbean 
Table 3: Influence of zinc seed coating on yield parameters and grain $\mathrm{Zn}$ contents of mungbean

\begin{tabular}{lllllll}
\hline $\begin{array}{l}\text { Zinc seed coating } \\
\text { levels }\left(\mathbf{g ~ k g}^{-1} \text { of seed) }\right.\end{array}$ & $\begin{array}{l}\text { Number of } \\
\text { seeds per pod }\end{array}$ & $\begin{array}{l}\mathbf{1 0 0} \text {-grain } \\
\text { weight }(\mathbf{g})\end{array}$ & $\begin{array}{l}\text { Grain yield per } \\
\text { plant }(\mathbf{g})\end{array}$ & $\begin{array}{l}\text { Biological yield } \\
\text { per plant }(\mathbf{g})\end{array}$ & $\begin{array}{l}\text { Grain Zn concentrations } \\
\left(\mathbf{m g ~ k g}^{-1}\right)\end{array}$ \\
\hline 0.0 & $6.72 \mathrm{e}$ & $5.55 \mathrm{e}$ & $3.08 \mathrm{e}$ & $6.77 \mathrm{e}$ & $35.33 \mathrm{c}$ \\
0.5 & $7.18 \mathrm{~d}$ & $5.62 \mathrm{~d}$ & $3.29 \mathrm{~d}$ & $7.28 \mathrm{~d}$ & $41.33 \mathrm{~b}$ \\
1.0 & $7.64 \mathrm{c}$ & $5.68 \mathrm{c}$ & $3.67 \mathrm{c}$ & $8.18 \mathrm{c}$ & $39.58 \mathrm{~b}$ \\
1.5 & $8.19 \mathrm{~b}$ & $5.83 \mathrm{~b}$ & $3.95 \mathrm{~b}$ & $10.01 \mathrm{~b}$ & $40.25 \mathrm{~b}$ \\
2.0 & $8.70 \mathrm{a}$ & $6.11 \mathrm{a}$ & $4.33 \mathrm{a}$ & $11.19 \mathrm{a}$ & $47.50 \mathrm{a}$ \\
LSD $(p \leq 0.01)$ & 0.45 & 0.05 & 0.16 & 0.31 & 1.92 \\
\hline
\end{tabular}

\section{Discussion}

Application of Zn through seed coating significantly enhanced plant growth, grain yield and grain $\mathrm{Zn}$ concentrations of mungbean (Tables 1-3). The better stand establishment, seedling growth and grain yield in $\mathrm{Zn}$ coated seeds might be attributed to involvement of $\mathrm{Zn}$ in lipid/protein/carbohydrates metabolism, acid nucleic/tryptophan synthesis and its role in various plant growth cascades including germination, photosynthesis, germination and tissue turgor (Rout and Das, 2003; Tsonev and Lidon, 2012). In a recent study Zaman et al. (2018) and Ullah et al. (2019) reported higher rice (Oryza sativa L.) and chickpea (Cicer arietinum L.) productivity in consequence of $\mathrm{Zn}$ seed coating.

In this study, increase in chlorophyll contents was due to involvement of $\mathrm{Zn}$ in chlorophyll formation which ultimately enhanced the synthesis of chlorophyll and carotenoids which are finally involved in the plant photosynthetic mechanism (Aravind and Prasad, 2003). Better root growth and increase in number of lateral roots due to $\mathrm{Zn}$ seed coating in this study (Figure $1 \mathrm{a}-\mathrm{f}$ ) might be attributed to the role of $\mathrm{Zn}$ in root cell elongation by reducing the free radical injury to cell (Cakmak, 2000). Early stand establishment and well-developed root system due to seed coating (Table 1; Figure 1) might improve nutrients uptake which resulted in more leaf area. Being units of plant assimilatory system, higher leaf area along with higher chlorophyll contents maybe resulted in more assimilates production which leads to significant improvement in yield related traits (Table 3). This improvement in grain yield due to $\mathrm{Zn}$ seed coating might be attributed to enhanced growth and improvement in yield related parameters (e.g. grain weight, grain number). Indeed, 100-seed weight, pods per plant and seeds per pod are important yield contributing traits in legumes and any improvement in these traits will improve the seed yield as was observed in this study. Masuthi et al. (2009) reported that $\mathrm{Zn}$ seed coating improved the grain weight of a legume crop. In an earlier study, Nadergoli et al. (2011) found that $\mathrm{Zn}$ application improved the number of seeds pod $^{-1}$ in green gram.
Yield improvement with $\mathrm{Zn}$ seed coating was possibly due to more $\mathrm{Zn}$ availability as $\mathrm{Zn}$ was available in the vicinity of emerging seedling which resulted in better stand establishment leading to improvement in yield contributing traits and ultimately grain yield (Table 3 ). Zinc application increases the chlorophyll synthesis, photosynthesis, which result in more photo assimilate formation and better yield (Rehman and Farooq, 2016; Rehman et al., 2018). Moreover, substantial improvement in pod formation and grain weight contributed to higher grain yield. Zinc supply in adequate amount helps in better seed setting owing to better pollen germination and fertilization (Pandey et al., 2006). Zinc seed coating also improved the grain $\mathrm{Zn}$ concentration (Table 3). The increased $\mathrm{Zn}$ accumulation in grains was possibly due to better root system (Figure 1), which might have helped in better soil exploration and uptake of $\mathrm{Zn}$ by mungbean roots. Moreover, presence of $\mathrm{Zn}$ in close vicinity of roots due to seed coating might have resulted in more Zn uptake (Rehman et al., 2018).

\section{Conclusion}

Mungbean seed coating with $\mathrm{Zn}$ improved the stand establishment, seedling growth, grain yield and grain $\mathrm{Zn}$ content than non-coated seed. Thus, the mungbean seeds should be coated with $2 \mathrm{~g} \mathrm{Zn} \mathrm{kg}^{-1}$ to achieve better stand establishment, grain yield and grain biofortification.

\section{References}

Aravind, P. and M.N.V. Prasad. 2003. Zinc alleviates cadmium induced toxicity in Ceratophyllum demersum, a fresh water macrophyte. Plant Physiology and Biochemistry 41:391-397.

Ashraf, M., M. Mueen-Ud-Din and N. Warrich. 2003. Production efficiency of mungbean (Vigna radiata L.) as affected by seed inoculation and NPK application. International Journal of Agriculture and Biology 5:179-180.

Bhandari, S. and M.R. Banjara. 2015. Micronutrients deficiency, a hidden hunger in Nepal: Prevalence, causes, consequences, and solutions. International Scholarly Research Noticies 15:1-9. 
Cakmak, I. 2000. Role of zinc in protecting plant cells from reactive oxygen species. New Phytologist 146:185-205.

Cakmak, I. 2008. Enrichment of cereal grains with zinc: Agronomic or genetic biofortification? Plant and Soil 302:1-17.

Darwish, D.S., E.G. El-Gharreib, M.A. El-Hawary and O.A. Rafft. 2002. Effect of some macro and micronutrients application on peanut production in a saline soil in ElFaiyum Governorate. Egypt Journal of Applied Science $17: 17-32$.

Ellis, R.A. and E.H. Roberts. 1981. The quantification of ageing and survival in orthodox seeds. Seed Science and Technology 9:373-409.

Fageria, N.K., M.B. Filho, A. Moreira and C.M. Guimarães. 2009. Foliar fertilization of crop plants. Journal of Plant Nutrition 32:1044-1064.

Farooq, M., A. Wahid and K.H.M. Siddique. 2012. Micronutrient application through seed treatments: A review. Journal of Soil Science and Plant Nutrition 12:125-142.

Haider, M.U., M. Farooq, A. Nawaz and M. Hussain. 2018a. Foliage applied zinc ensures better growth, yield and grain biofortification of mungbean. International Journal of Agriculture and Biology 20:2817-2822.

Haider, M.U., M. Hussain, M. Farooq and A. Nawaz. 2018b. Soil application of zinc improves the growth, yield and grain zinc biofortification of mungbean. Soil and Environment 37:123-128.

Koca, Y.O. 2016. Effect of nutrients supply with foliar application on growing degree days, protein and fatty yield of corn in Mediterranean conditions. Scientific Papers-Series A, Agronomy 59:318-326.

Korishettar, P., S.N. Vasudevan, N.M. Shakuntala, S.R. Doddagoudar, S. Hiregoudar and B. Kisan. 2016. Seed polymer coating with $\mathrm{Zn}$ and Fe nanoparticles: An innovative seed quality enhancement technique in pigeonpea. Journal of Applied and Natural Science 8:445-450.

Masuthi, D., B.S. Vyakaranahal and V.K. Deshpande. 2009. Influence of pelleting with micronutrients and botanical on growth, seed yield and quality of vegetable cowpea. Karnataka Journal of Agricultural Sciences 22:898900.

Nadergoli, M.S., M. Yarnia and F.R. Khoei. 2011. Effect of zinc and manganese and their application method on yield and yield components of common bean (Phaseolus vulgaris L. CV Khomein). Middle-East Journal of Scientific Research 8:859-865.

Pandey, N., G.C. Pathak and C.P. Sharma. 2006. Zinc is critically required for pollen function and fertilization in lentil. Journal of Trace Elements in Medicine and Biology 20:89-96.
Prasad, A. S. 1995. Zinc: An overview. Nutrition 11:93-99.

Rehman, A. and M. Farooq. 2016. Zinc seed coating improves the growth, grain yield and grain biofortification of bread wheat. Acta Physiolgiae Plantarum 38:238.

Rehman, A., M. Farooq, L. Ozturk, M. Asif and K.H.M. Siddique. 2018. Zinc nutrition in wheat-based cropping systems. Plant and Soil 422:283-315.

Rout, G.R. and P. Das. 2009. Effect of metal toxicity on plant growth and metabolism: I. Zinc. p.873-884. In: Sustainable Agriculture, Springer Netherlands.

Shanmugasundaram, S. 2004. Improving income and nutrition by incorporating mung bean in cereal fallows in the indo-gangetic plains of South Asia. In: Proceedings of the Final Workshop and Planning Meeting, 27-31 May 2004, Punjab Agricultural University, Ludhiana, Punjab, India.

Solomons, N.W. 1998. Mild human zinc deficiency produces an imbalance between cell-mediated and humoral immunity. Nutrition Reviews 56:27-28.

Steel, R.G.D., J.H. Torrie and D.A. Dicky. 1997. Principles and Procedures of Statistics: A Biometrical Approach, 3rd Edition, McGraw Hill Book Co. Inc. New York, pp: $400-428$.

Tsonev, T. and F.J.C. Lidon. 2012. Zinc in plants - An overview. Emirates Journal of Food Agriculture 24:322-333.

Ullah, A., M. Farooq, M. Hussain, R. Ahmad and A. Wakeel. 2019. Zinc seed coating improves emergence and seedling growth in desi and kabuli chickpea types but shows toxicity at higher concentration. International Journal of Agriculture and Biology 21:553-559.

Usman, F., A. Hassan and A. Ahmad. 2007. Arterial ischemic stroke with protein deficiency in Pakistan. Rawal Medical Journal 32:205-207.

Wiatrak, P. 2013. Influence of seed coating with micronutrients on growth and yield of winter wheat in Southeastern Coastal Plains. American Journal of Agricultural and Biological Sciences 8:230-238.

Zaman, Q.U., Z. Aslam, M. Rashid, A. Khaliq and M. Yaseen. 2018. Influence of zinc fertilization on morpho-physiological attributes, growth, productivity and hematic appraisal of paddy rice. Journal of Animal and Plant Sciences 28:778-790.

Zafar, S., M.Y. Ashraf, S. Anwar, Q. Ali and A. Noman. 2016. Yield enhancement in wheat by soil and foliar fertilization of $\mathrm{K}$ and $\mathrm{Zn}$ under saline environment. Soil and Environment 35:46-55. 